\title{
Development of the Trade Relations Intensity between the EU27 and the United Kingdom in the Context of Brexit with a Focus on the Member States
}

DOI 10.18267/pr.2021.krn.4816.11

\author{
Simona Krivosudská \\ ORCID iD: 0000-0002-8784-5254 \\ simona.krivosudska@euba.sk \\ University of Economics in Bratislava, Faculty of Commerce, International Trade \\ Department \\ Bratislava, Slovakia
}

\begin{abstract}
The future development of trade relations between the EU27 and the United Kingdom has received attention from the British referendum in 2016. As much as $64 \%$ of the EU's exports (intra + extra-regional exports) remain within the integration group. The aim of the paper is to examine, based on the development of the trade relations intensity between the EU27 and the United Kingdom, which EU member state are affected the most by Brexit. To examine trade intensity we calculated the trade intensity index based on the data of EUROSTAT and ITC. The intensity of trade relations has a declining trend on both sides. However, the result of the index showed higher intensity on the EU's side. An agreement on future trade relations is crucial for both partners. Ireland as the country with the highest trade intensity in trade with the UK is the EU member affected the mostly by Brexit in terms of its exports and imports.
\end{abstract}

Keywords: Brexit, European Union, member states, trade intensity

JEL Classification codes: F10, F15

\section{INTRODUCTION}

In the last two decades, the EU has had to face several challenges that have tested its coherence and unity, such as the global economic and financial crisis, the debt crisis in the euro area, the migration crisis, or the so-called Brexit. In the referendum in 2016, the British people decided to restore the country's sovereignty and take control over the economy by leaving the integration block. The uncertain process of Britain's withdrawal from the EU with a threefold postponement of Brexit, a decline in business investment, and foreign demand, led to a reduction in UK GDP growth from 2.4\% in 2015 (pre-Brexit value) to $1.4 \%$ in 2019 . In the case of the EU27 decline in GDP growth from $2.3 \%$ to $1.6 \%$ was recorded over the same period (Eurostat, 2020).

The United Kingdom (UK) formally left the EU on 31 January 2020. The transitional period lasted 11 months until December 2020. During this period, the EU and the UK have negotiated an agreement on future relations. In addition, the difficult negotiations on the EU27-UK agreement were complicated by restrictive measures. They were introduced by all economies to slow the COVID-19 pandemic spread. This has led to a downturn in global economic activity as a decline in business investment, industrial activity, or a drop in demand in almost all sectors of the economy. The British economy has been hit even harder by this situation because it faced a recession even before the COVID-crisis due to the uncertainty caused by the Brexit. 
Because of the UK leaving, the EU has been losing its long-term strategic partner. Nevertheless, closer relations with the EU mean better economic prospects for Britain, as the EU27 has been one of the world's largest trade players for several decades. With the EU's gradual enlargement by new members, the economic and negotiating power of the bloc has increased, which has also strengthened the EU's competitiveness (Ružeková et al., 2020). Individual EU countries will be affected by Brexit in different ways and different extents. Since 1 January 2021 has been provisionally applied a new Trade and Cooperation Agreement (TCA), which can mitigate the effects of hard Brexit. This agreement goes beyond traditional free trade agreements and provides the basis for maintaining a long-standing partnership and cooperation. It can be expected that all EU countries will be touched to a greater or lesser extent by the political or economic Brexit impact. It depends on their historical ties with the UK, geographical distance, shares of mutual trade, or connections to specific industries and production. For this reason, we decided to examine the development of trade intensity between the EU27 and the UK, focusing also on selected member countries.

\section{LITERATURE REVIEW}

The EU represents a milestone of European stability and prosperity. The EU has achieved a strong position on the global trade scene. It results from the EU's speaking with one voice and its common trade strategies. According to Meunier (2005), the size of the European single market, combined with the collective nature of the common commercial policy, has made the EU a major competitor with enormous negotiating power. EU trade strategies are focused on growth, prosperity, and job creation for trade and investment, including for non-EU countries. The position of the EU as a trading power or a global player has been explored by several authors, e.g. Bretherton and Vogler (2006) or Kittová (2020).

This topic is still relevant in the context of current problems and challenges which the EU has to face, especially concerning Brexit (Smith, 2019). The arrangement of EU-UK trade relations after Brexit has naturally raised many questions about possible future scenarios and their impact on the economies of the EU Member States and the UK (European Parliament, 2018; Bertelsmann Foundation, 2019; Wenz, 2020). All available studies agree that either scenario would severely disrupt trade ties and incur economic costs on both sides. According to A. Belke and D. Gros (2017), these costs will be on both sides. On the EU side would be a lesser extent. Not only because it is economically approximately five times larger than the UK, but also for the greater market power of European companies.

The European Committee of the Regions (2018) considered the six key economic sectors of the EU27, which would be affected by the UK's withdrawal, namely transport vehicles; machinery; electronics; textile and furniture; vegetables, foodstuffs, and wood; chemicals and plastics. According to this study, the sector of transport vehicles was exported the most from Germany, Romania, and France. The machinery sector was exported by Germany and Italy. The Electronics sector was mainly exported to the UK by the Slovak Republic, Czech Republic, Romania. In the export of textiles and furniture sector dominated Italy, Portugal, and Bulgaria. The vegetables, food, and wood sector was exported from Greece and France, and the chemical and plastic sector from France and Germany.

KPMG study (2017) estimated which EU member states will be the most affected by the UK's exit from the single market based on their exports of goods and services. According to this study, Ireland, Slovakia, Spain, and Germany will be touched the most by the Brexit impact. Brexit barriers will affect many industries. The most commonly used example was German car production, $14 \%$ of car production in Germany was exported to Britain. According to KPMG's calculations, $14 \%$ of French wine, $10 \%$ of Belgian chocolate, $26 \%$ of Danish sausage, and $15 \%$ of Greek cheese were exported to the British market in 2015. 
In Global Counsel study (2015), member states were divided into 4 groups from high to low exposure to Brexit. In the group of high exposure were included Netherlands (due to its FDI in Britain), Ireland (deeply integrated with the UK in terms of trade, supply chains, migration, language, and culture; the only member state with a land border with the UK) and Cyprus (due to historical and cultural factors as Cyprus was a British colony and still is a member of the Commonwealth). On the other side, there are countries in the south-east of the EU with a low exposure as Slovenia, Croatia, Romania, and Italy, which would reflect their distance and different political cultures. This does not, however, mean that they would be without any direct or indirect consequences of the Brexit. There are many other studies dealing with the Brexit impact, using different research techniques and data sets (Los et al., 2017; Billing et al., 2019). Chen et al. (2018) also confirmed that for EU member states and regions located in the south, far east, and far north of Europe, expected economic exposure to Brexit is a very minimal compared to countries and regions in continental Europe near the UK.

\section{METHODOLOGY}

The aim of the paper is to examine, based on the development of the trade relations intensity between the EU27 and the United Kingdom, which EU member state are affected the most by Brexit.

To achieve the aim several research methods were used, such as analysis, induction, deduction, comparison, and mathematical-statistical methods. Databases of the Eurostat and International Trade Centre (ITC) were used to obtain data for the analysis of the current state of the research topic, and for the calculation of the trade intensity index. Figures were processed with MS Excel. EU27 represents the current twenty-seven members of the integration block (without the UK) and serves to examine trade relations with the UK in the context of Brexit.

The Trade Intensity Index (TI) is used to assess the values of trade between two countries based on their world trade position and the size of the economy. It assesses whether countries' bilateral trade is greater or less than would be expected based on their position in the world economy. According to $\mathrm{Ng}$ and Yeats (2003), the main limitation of this index is that it does not distinguish between objective (geographical distance, the similarity in economic structure) and subjective barriers of trade (tariff and non-tariff barriers). Objective barriers affect the calculation of the trade intensity (geographically distant countries have a lower TI index), while subjective barriers can be reduced or eliminated in the short term (Bao \& Chen, 2013). The TI is determined as the share of exports of country $i$ to country $j$ on total exports of country $\mathrm{i}$ to the world, divided by the proportion of total world exports to the country $\mathrm{i}$ to the total value of world exports (World Bank, 2010).

The trade intensity index is calculated as:

$T I i j=\frac{(\mathrm{xij} / \mathrm{Xit})}{(\mathrm{xwj} / \mathrm{Xwt})}$

where:

xij represents the value of exports from country i to country $j$;

Xit represents the value of the i country's total exports to the world;

$x w j$ represents the value of total world exports to country $j$;

Xwt represents the total value of world exports.

The TI reaches a value in the range $\langle 0,+\infty\rangle$. If the value of the index is equal to 1 , it means that country $i$ exports to country $j$ the exact ratio of exports that country $j$ belongs to, given 
its share in world imports. If the value of the index is higher than 1 , trade flows between the countries are more intense than would be expected given the importance of the partner country in the world economy. This means that the country $i$ exports to the country $j$ more goods than to the rest of the world. This means an intensive trade relationship. If the index value is less than 1 , the intensity of trade is lower than would be expected given the importance of the economy in world trade (The World Bank, 2013).

\section{RESULTS AND DISCUSSION}

The turmoil in the world economy, the slowdown in economic growth, or the spread of populism are manifested more often in the sceptical of countries about the benefits of free trade. Vise versa, some countries rather support the idea of introducing protectionist trade policies. The EU was also touched by a significant disruption of previous liberalization and integration efforts when the British people decided in 2016 to vote for leaving the EU. The Brexit took place in January 2020. The UK has decided to leave the integration block after 43 years and take back control of its economy. The EU has lost a market of over 65 million population, but still represents the largest single market in the world economy.

The EU as an integration block is the UK's largest trading partner. In 2019, the UK exported up to $43 \%$ of its total exports to the EU. UK imports from the EU accounted for up to $52 \%$ of total imports. Exports of services to the EU in 2019 accounted for up to $42 \%$ of total British exports of services. In general, the decline of British exports share to the EU by 11 percentage points (since 2002) and imports share from the EU by 5 percentage points (since 2006) can be observed. The UK's withdrawal from the EU triggered a discussion on the future functioning of mutual trade relations, and therefore we examined the development of EU27-UK merchandise trade in 2012-2019 (Fig. 1).

\section{Fig. 1 Development of EU27-UK trade in 2012 - 2019 (in billion EUR)}

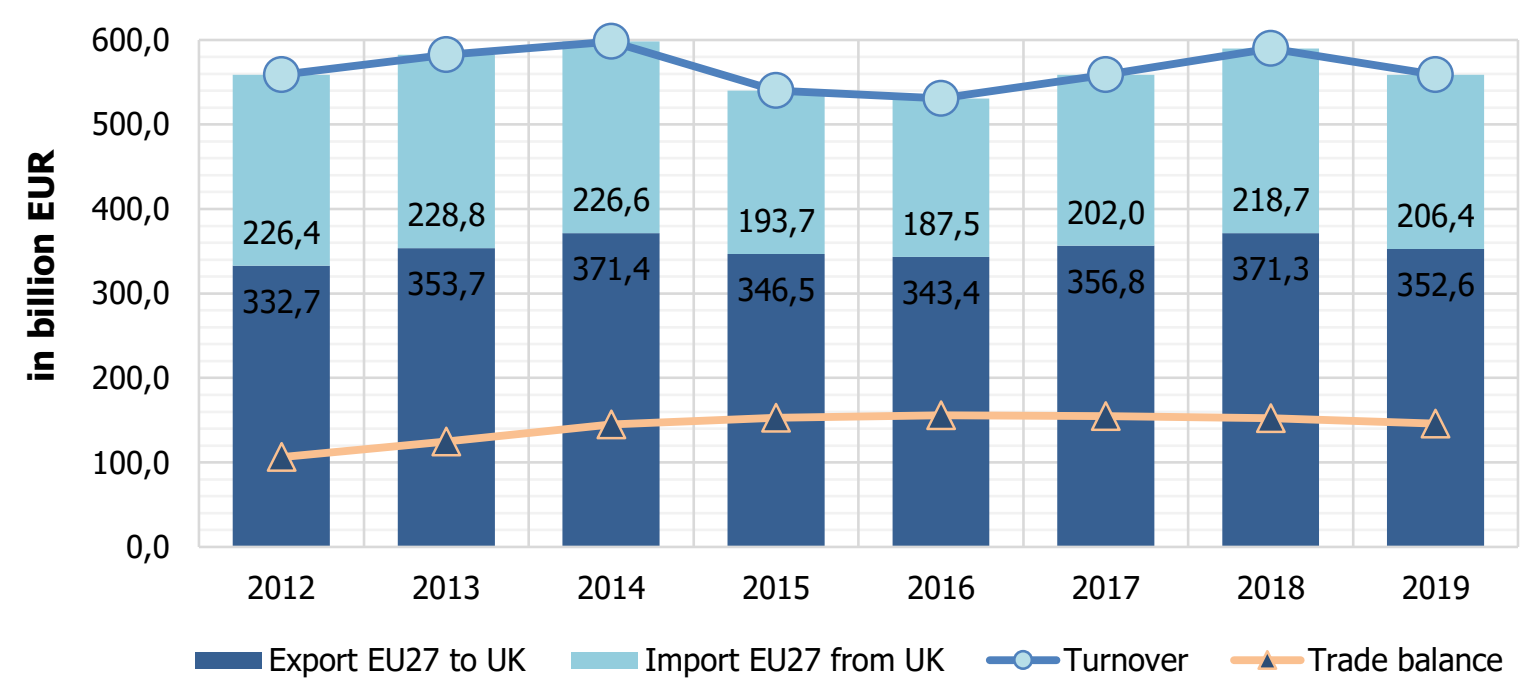

Source: own processing based on data from ITC, 2020

As it can be seen, the EU27 exported to the UK goods in volume of 332.7 billion EUR. By 2019, exports increased up to 352.6 billion EUR, which represents an increase of $6 \%$. The highest export volumes were reached in 2014 (371.4 billion EUR). On the contrary, the lowest were reached in 2016 (EUR 343.4 billion). In the observed period, the EU27 exports to the UK had a growing trend. In 2012, the EU27 imported from the UK goods in volume of 226.4 billion 
EUR. It decreased by almost $9 \%$ to 206.4 billion EUR by 2019 . The lowest volumes of imported goods were in 2015 in the amount of 187.5 billion EUR. The EU27 imports from the UK were prone to volatility with a declining trend.

The UK's withdrawal from the EU can destabilize the individual economies of the Union, which are most involved in trade with the UK. In 2019, merchandise trade with the UK accounted for $4.9 \%$ of the EU27's foreign trade turnover. According to the UK's foreign trade turnover, the largest UK's trading partner was in 2019 the EU27 with a share of 48.1\% (Fig. 2), which represented a volume of up to 498.3 billion EUR. The high share can be attributed to the strength of the integration block of 27 countries and the fact that until the end of 2020 the UK was still part of the Union and its trade was closely linked to EU Member States. The following Fig. 2 shows the UK's trading partners in the terms of their foreign trade turnover.

Fig. 2 The main trade partners of the UK based on foreign trade turnover in 2019 (in \%)

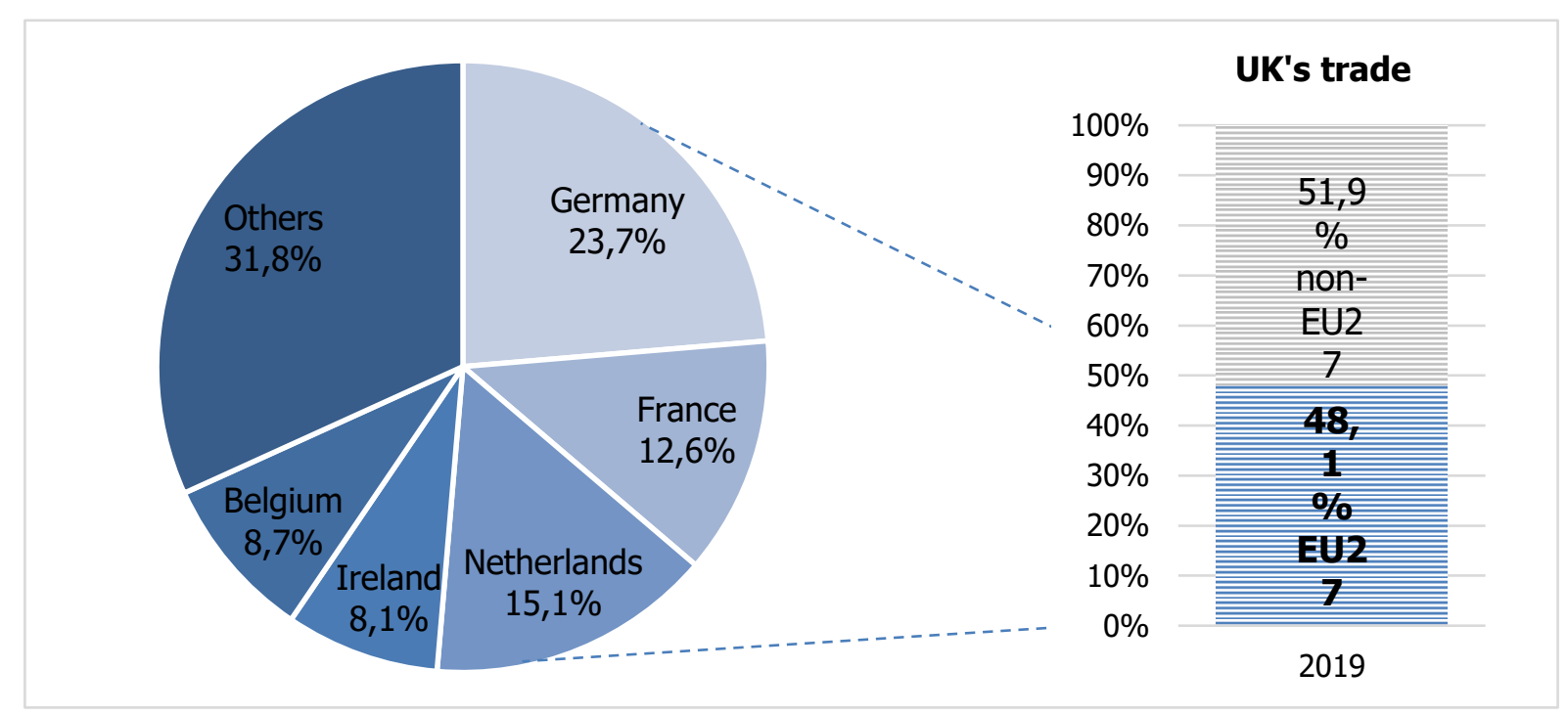

Source: Own processing based on data from EUROSTAT, 2020.

The UK's most important trading partners from EU countries were Germany with a share of $23.7 \%$ in the total UK's foreign trade turnover with the EU27, the Netherlands (15.1\%), France $(12.6 \%)$, Belgium (8.7\%) and Ireland (8.1\%).

Examining EU27 exports, we found that the largest exporters of goods to the UK in terms of volume in 2019 were Germany (79.0 billion EUR), Netherlands (39.9 billion EUR), France (33.7 billion EUR), Belgium (30.3 billion EUR) and Ireland (15.8 billion EUR). In 2019, the largest importers of goods from the UK by volume of imports were Germany (37.9 billion EUR), Netherlands (24.7 billion EUR), France (21.2 billion EUR), Ireland (20.4 billion EUR), and Belgium (16.7 billion EUR) (ITC, 2020).

It is important to examine the volumes of the EU27-UK trade as in the previous paragraph. We also consider as important to examine trade shares of EU countries with the UK. Tab. 1 shows the EU Member States that have the largest share of exports to the UK concerning their total exports and the countries that have the largest share of imports from the UK in relation to their total imports. 
Tab. 3 The EU's countries with the largest share of trade with the UK (in \%)

\begin{tabular}{|c|c|c|c|c|c|c|c|}
\hline \multicolumn{4}{|c|}{$\begin{array}{l}\text { The UK's Share in the Exports of the EU } \\
\text { Members }\end{array}$} & \multicolumn{4}{|c|}{$\begin{array}{l}\text { The UK's Share in the Imports of the EU } \\
\text { Members }\end{array}$} \\
\hline \multicolumn{2}{|c|}{ EU Member States } & \multirow{2}{*}{\begin{tabular}{|l|}
2018 \\
$11,4 \%$
\end{tabular}} & \multirow{2}{*}{$\begin{array}{l}2019 \\
10,3 \%\end{array}$} & \multicolumn{2}{|c|}{ EU Member States } & \multirow{2}{*}{$\begin{array}{l}2018 \\
21,9 \%\end{array}$} & \multirow{2}{*}{$\begin{array}{l}2019 \\
22,5 \%\end{array}$} \\
\hline 1 & Ireland & & & 1 & Ireland & & \\
\hline 2 & Netherlands & $8,1 \%$ & $7,7 \%$ & 2 & Malta & $8,3 \%$ & $18,5 \%$ \\
\hline 3 & Belgium & $7,9 \%$ & $7,6 \%$ & 3 & Cyprus & $6,6 \%$ & $7,0 \%$ \\
\hline 4 & France & $6,8 \%$ & $6,8 \% \Leftrightarrow$ & 4 & Netherlands & $6,0 \%$ & $5,4 \%$ \\
\hline 5 & Spain & $6,3 \%$ & $6,5 \%$ & 5 & Sweden & $5,0 \%$ & $4,5 \%$ \\
\hline
\end{tabular}

Source: own processing based on data from ITC, 2020

In 2019, Ireland had the highest share of exports to the UK in its total exports $(10.3 \%)$, followed by the Netherlands (7.7\%), Belgium (7.6\%), France (6.8\%), and Spain (6.5\%). Only Spain recorded a slight increase of 0.2 percentage points compared to 2018.

In 2019, the highest share of imports from the UK in total member state's imports had Ireland $(22.5 \%)$, followed by Malta $(18.5 \%)$, Cyprus $(7.0 \%)$, Netherlands $(5.4 \%)$, and Sweden (4.5\%). Compared to 2018 , the share of imports increased by 0.6 percentage points in Ireland, by as much as 10.2 percentage points in Malta, and by 0.4 percentage points in Cyprus.

\subsection{The trade intensity development of the EU27 and the United Kingdom}

The TI was used to assess mutual EU27-UK merchandise trade. The index examines whether the value of trade between the EU27 and the UK is greater or less than would be expected based on their position in international trade. Fig. 3 shows the trade intensity of the EU27 and the UK in 2012-2019.

Fig. 3 Development of the EU27-UK and the UK-EU27 trade intensity in 2012 - 2019

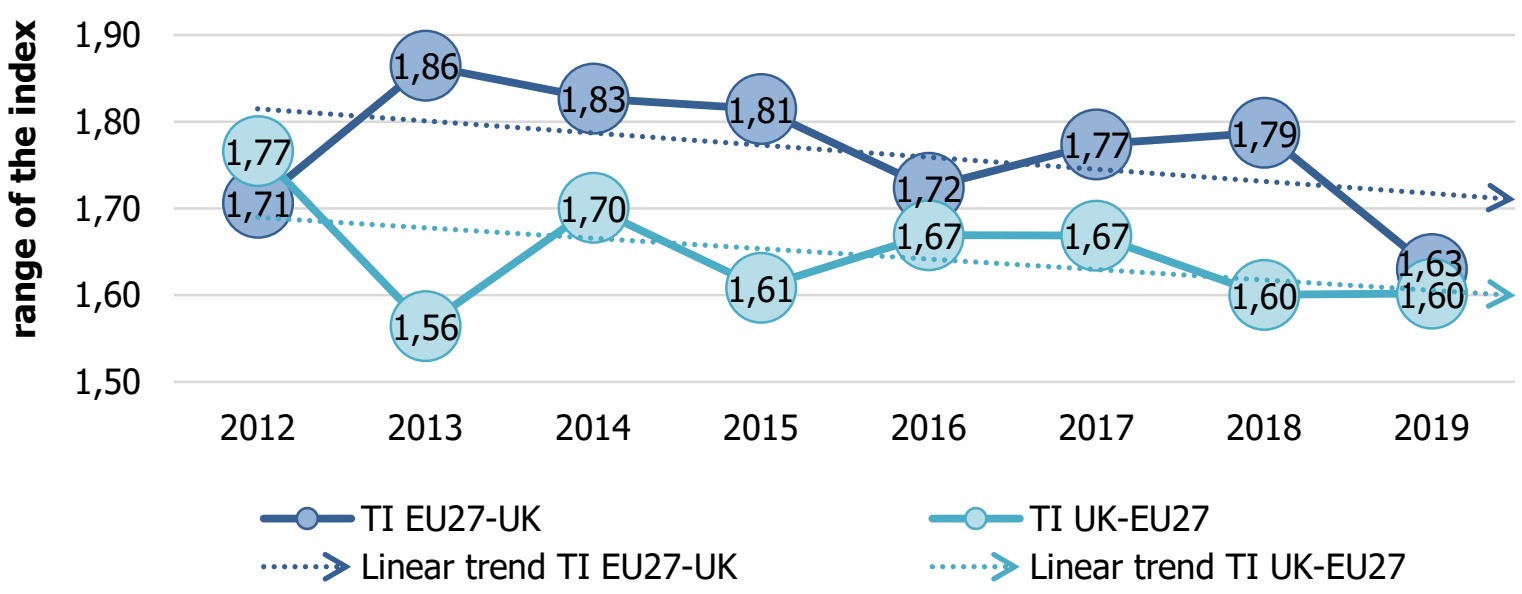

Source: own processing based on data from ITC, 2020

Fig. 3 shows that in the observed period, the EU27-UK trade intensity was higher than 1. It indicates a high intensity of foreign trade. The values of the trade intensity index prove the existence of bilateral trade between partners, which also follows from the UK's membership 
in the integration bloc. The index reached 1.86 points in 2013 , which was the maximum in the observed period. Until 2016, it had a declining tendency. The value of the index rose again from 1.72 points in 2016 to 1.79 points in 2018. In 2019, the lowest index value in the observed period (1.63 points) was recorded. Despite fluctuations, the EU27 and the UK recorded intensive trade because index values did not fall below 1.0 point.

The value of the UK-EU27 trade intensity in 2012-2019 indicated intensive bilateral trade between them. The UK-EU27 trade intensity in 2012 even slightly exceeded the EU27-UK trade intensity in the same year. In 2013, compared to the previous year, there was a decrease by 0.21 points from 1.77 to 1.56 points, which was also the lowest value in the observed period. In 2014, the value of the index increased again to 1.70 points. In the following year, it fell again to 1.61 points. In 2016 and 2017, the value of the index maintained the same value of 1.67 points. In 2018 , the value fell again to 1.60 points and maintained the same value also in 2019. Despite the volatility of the TI index values, we can still conclude that the UK and the EU27 have had intensive trade relations.

In the observed period, the average EU27-UK values of trade intensity reached 1.77 points, while the average of the UK-EU27 trade intensity was lower by 0.12 points and reached the value of 1.65 points. The averages of the TI index showed still intensive bilateral trade. The linear trend for both predicts a downturn. It can be caused by four years of uncertainty about Brexit, difficult negotiations, and lengthy negotiation processes on the trade agreement provisionally applied from January 2021.

We consider it important to note that the heterogeneity of the EU can lead to distorted the TI index results. It is caused by the averaging of values for 27 member states in the integration block. We are aware that the different member states may achieve different trade intensity values with the UK. Fig. 4 shows the trade intensity of selected EU27 member states (chosen based on the volume of their turnover with the UK) and the UK. The TI index was calculated for Germany, France, Ireland, Netherlands, and Belgium in 2012-2019.

Fig. 4 The trade intensity development of the EU27 member states and the UK in 2012 2019
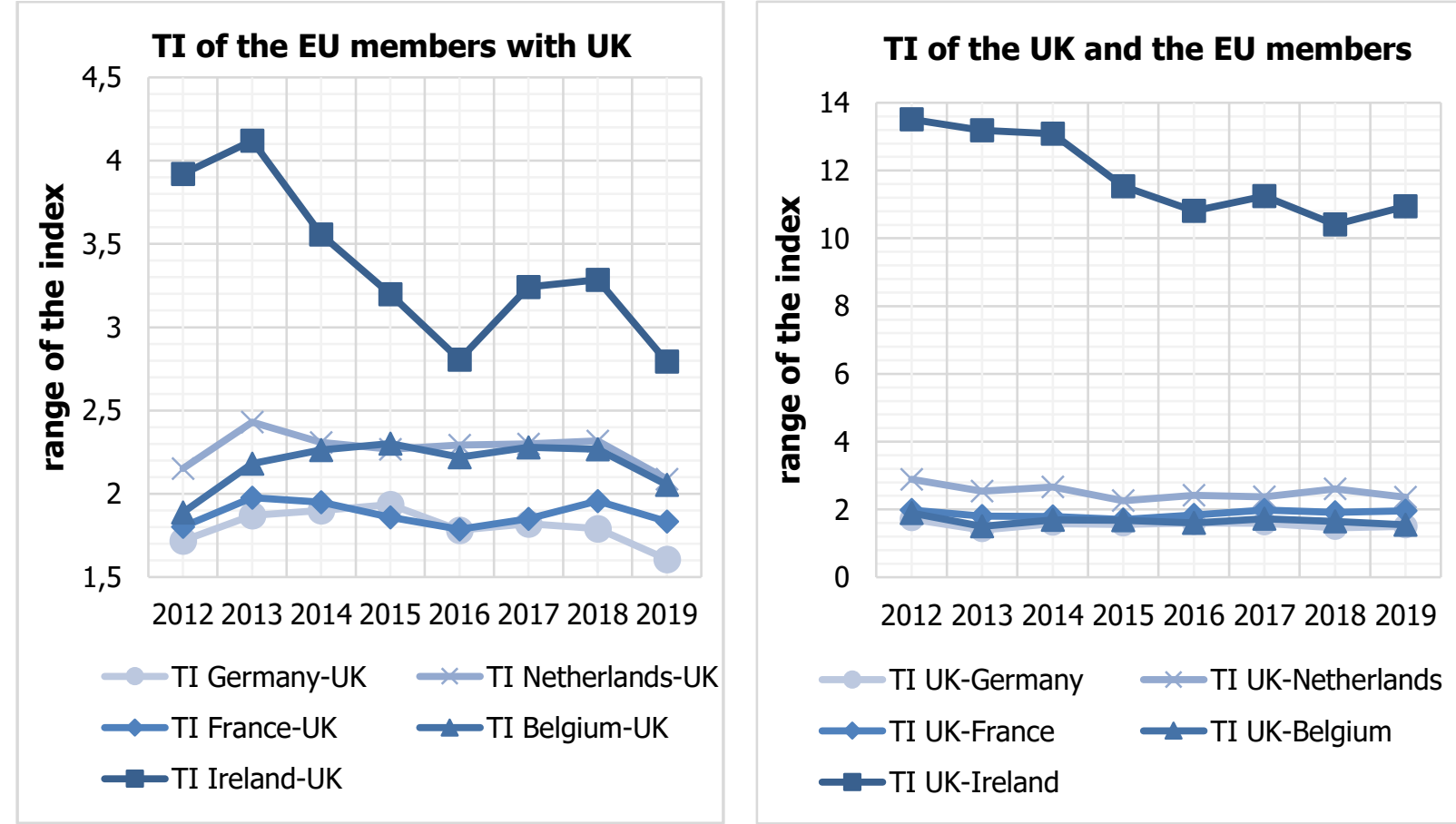

Source: own processing based on data from ITC, 2020 
The trade intensity of selected EU member states was greater than 1 in 2012-2019, which indicates intensive trade relations with the UK. In the observed period, the trade intensity of Germany, France, Belgium, and the Netherlands ranged from 1.6 to 2.4.

In 2019, all five countries recorded a decrease in intensity compared to the previous year. In 2019, the lowest intensity was reached by Germany (1.6) and France (1.8); the intensity of Belgium and the Netherlands was at the value of 2.1 points. The intensity of Ireland's trade relations with the UK was the highest in 2013 at 4.1 points. By 2016, it was downturned by one third to 2.8 points. In 2017 - 2018, their trade relations intensified again, but in 2019 eased to 2.8 points. The decline of Ireland's trade intensity with the UK was caused by the diversification of its exports, which means that Ireland increased trade with other partners. This was evident in trade with the USA, where Ireland's exports increased by 10.7 percentage points to $30.8 \%$ in 2019 compared to 2012 (ITC, 2020).

In 2012-2019, the trade intensity values of the UK and selected EU member states were also higher than 1, which indicates an intensive bilateral trade. The trade intensity between the UK and Germany, France, Belgium, and Netherlands ranged from 1.5 to 2.0 points. In 2012, the trade intensity of the UK with Ireland was 13.5 points, indicating very strong trade ties. Although by 2019 , a decrease in intensity was reached, the value of trade intensity was still very (11.0 points).

\section{CONCLUSION}

Integrating countries into the EU has brought appropriate economic benefits to its member states. Despite this fact, increasing euroscepticism has begun to manifest itself in recent years. This mistrust of the EU's effectiveness and importance resulted in a British referendum in 2016. This is an unprecedented event in the EU's history. Brexit raised concerns about the departure of other members from the block and the possible disintegration of the EU.

The UK left the EU's single market and customs union on 1 January 2021. Despite the length of the difficult withdrawal process, the Trade and Cooperation Agreement has been reached, which has represented a significant step for the maintenance of a long-standing partnership between the EU27 and the UK. Almost until the end of the transitional period, hard Brexit threatened, which would lead to the reintroduction of tariffs and other trade barriers. The scenario without an agreement would have the greatest impact on the economies of individual member states and also on the British economy.

The aim of the paper was to examine, based on the development of the trade relations intensity between the EU27 and the United Kingdom, which EU member state are affected the most by Brexit. Germany, Netherlands, and France would be affected by Brexit impact the most based on trade volumes. Based on the UK's share of the total country's export/import and also based on trade intensity (determined by the TI), Ireland would be affected by Brexit impact the most. The high intensity of trade relations between Ireland and the UK resulted from historical ties, geographical proximity, and deep integration of EU member states.

The values of the trade intensity index showed that it makes sense for the EU27 and the UK to maintain preferential trade relations after Brexit. The reintroduction of trade barriers would disrupt natural trade flows, which will lead to negative effects on both sides. Trade and Cooperation agreement is beyond traditional free trade agreements, which only confirms that our assumptions are correct. To date, there has never been reached such a comprehensive agreement between the EU and a third country.

For the EU was the 2020 milestone in its history. In this crucial and challenging period, the EU showed there is still a strong sense of building an integration block. For decades, it was confirmed by the EU's leading position in international trade. The EU dispelled any doubts and 
scepticism about the importance of integration. In 2020, the EU showed its strength in coherence and unity, in particular negotiations with the UK or in the fight against the COVID-19 pandemic.

\section{ACKNOWLEDGEMENT}

This paper is a part of a research project of the Ministry of Education, Family and Sports of the Slovak Republic VEGA (in the period 2020 - 2022) No. 1/0777/20: Belt and Road initiative - opportunity or threat for the EU and Slovak export competitiveness?

This contribution is part of the internal grant project PMVP No. I-21-110-00 of the University of Economics in Bratislava for young teachers, researchers and doctoral students entitled "The impact of geopolitical changes on the EU's foreign trade relations with selected countries in the 21 st century".

\section{REFERENCES}

Bao, X., \& Chen, W.-Ch. (2013). The Impacts of Technical Barriers to Trade on Different Components of International Trade. Review of Development Economics, 17(3), 447-460. https://doi.org/10.1111/rode.12042

Bertelsmann Foundation. (2019). Estimating the impact of Brexit on European countries and regions. Policy Paper. Retrieved 16 January 2021, from https://www.bertelsmannstiftung.de/fileadmin/files/user_upload/EZ_Estimating_the_Impact_of_Brexit_2019_ENG.pdf.

Billing, C., McCann, P., \& Ortega-Argilés, R. (2019). Interregional inequalities and UK subnational governance responses to Brexit. Regional Studies, 53(5), 741-60. https://doi.org/10.1080/00343404.2018.1554246

Bretherton, Ch., \& Vogler, J. (2006). The European Union as a global actor. Routledge : New York.

European Committee Of The Regions. (2018). Assessing the impact of the UK's withdrawal from the EU on regions and cities in EU27. Retrieved 19 January 2021, from https://cor.europa.eu/Documents/Migrated/news/impact-brexit.pdf.

European Parliament. (2018). Future trade relations between the EU and the UK: options after Brexit. Retrieved 13 January 2021, from http://www.europarl.europa.eu/ RegData/etudes/STUD/2018/603866/EXPO_STU(2018)603866_EN.pdf.

Eurostat. (2020). Statistics A-Z. Retrieved 25 January 2021, from https://ec.europa.eu/eurostat/web/main/data/statistics-a-z/abc.

Global Counsel. (2015). BREXIT: The impact on the UK and the EU. Retrieved 7 January 2021, from https://brexit.hypotheses.org/files/2017/01/Global-Counsel_Impact_of_Brexit.pdf.

Chen, W., Los, B., McCann, P., Ortega-Argilés, R., Thissen, M., \& van Oort, F. (2018). The continental divide? Economic exposure to Brexit in regions and countries on both sides of the Channel. Papers in Regional Science, 97(1), 25-54. https://doi.org/10.1111/pirs.12334

ITC. (2020). Trade statistics for international business development. Retrieved 26 January 2020, from https://www.trademap.org/.

Kittová, Z. (2020). The European Union as a Major Trading Player in the Global Economy. Handbook of Research on Social and Economic Development in the European Union. Herschley, USA : IGI Global. 
KPMG. (2017). Brexit: The view from Europe. Retrieved 16 January 2020, from https://home.kpmg/content/dam/kpmg/sk/pdf/2017/brexit-the-view-from-europe.pdf.

Los, B., McCann, P., Springford, J., \& Thissen, M. (2017). The mismatch between local voting and the local economic consequences of Brexit. Regional Studies, 51(5), 786-99. https://doi.org/10.1080/00343404.2017.1287350

Meunier, S. (2005). Trading Voices: The European Union in International Commercial Negotiations. Princeton, NJ: Princeton University Press.

Ng, F. \& Yeats, A. (2003). Major Trade Trends in East Asia : What are their Implications for Regional Cooperation and Growth? Policy Research Working Paper No. 3084. Washington, DC. World Bank.

Ružeková, V., Kittová, Z., \& Steinhauser, D. (2020). Export Performance as a Measurement of Competitiveness. Journal of Competitiveness: Scientific Journal from the Field of Management and Economics, 12(1), 145-160. https://doi.org/10.7441/joc.2020.01.09

Smith, M. (2019). The European Union and the global arena: In search of post-brexit roles. Politics and Governance, 7(3), 83-92. http://dx.doi.org/10.17645/pag.v7i3.2133

The World Bank. (2013). Online Trade Outcomes Indicators. Retrieved 21 January 2020, from http://wits.worldbank.org/WITS/docs/ TradeOutcomes-UserManual.pdf.

The World Bank. (2010). Trade Indicators. Retrieved 21 January 2020, from http://wits.worldbank.org/wits/wits/witshelp/Content/Utilities/e1trade_indicators.htm.

Wenz, L. (2020). Post-Brexit no-trade-deal scenario: Short-term consumer benefit at the expense of long-term economic development. PLOS ONE, 15(9). https://doi.org/10.1371/journal.pone.0237500 